\title{
システム・ソフトウェア開発
}

\section{野外調查データを用いた地質境界面推定データ作成プログラム 『Georiginer』の開発}

\author{
梶山 敦司*・居川 信之**・塩野 清治***

\section{Development of Data Origination Program『Georiginer』 to Estimate Geological Boundary Surfaces Based on Imaged Data}

\author{
Atsushi KAJIYAMA*, Nobuyuki IKAWA** and Kiyoji SHIONO***
}

\begin{abstract}
Logical model of geological structure is expressed logical relation between boundary surfaces and geologic bodies. By using this logical relation, we can give a constraint to data in order to estimate geological boundary surfaces from the distribution position of geologic body. In this present research, we developed the data origination program "Georiginer" to estimate the geological boundary surface using this character of logical model of geological structure. This program can make the data for estimating the boundary surface from data distribution map, logical model of geological structure data, point data and strike \& dip data corresponding to each point.
\end{abstract}

Key words : Logical model of geological structure, Boundary surface, Imaged data, Georiginer

\section{1.はじめに}

近年，コンピュータ上で三次元地質モデルの構築を行う ために，GIS を用いた構築方法(Masumoto.et al;2004),etc)や 専用のソフトウェア(Geomodel2003(米澤ほか;2004)), GEORAMA (山根ほか; 1992)など)を用いる方法が開発されてい る。また，これらの技術を用いることによって，三次元的 に地質構造を可視化する手法が，調査結果の報告書を作成 する段階で使用されるようになった。コンピュータ上で構 築された三次元地質モデルに対して，3Dビューワーを用 いることによって任意断面を容易に描くことができ，容易 に断面図の作成を行えるなどの多くの利点が存在するため である。また，地質構造の三次元分布を一般的に示される 地質図(平面図・断面図)から読むためにはある程度の専門知 識が必要であるが，三次元地質モデルを用いることによっ て地質学の知識を持たない第三者や発注者に対しても容易 に地質調査の各種結果を説明することが可能となる。ま た，ハザードマップの作成，環境問題や地下利用などの各 種検討にも三次元地質モデルを用いることができる。

三次元地質モデルは，地質体と境界面の論理的関係(地質
構造の論理モデル)と面の形状で構成される。地質構造の論 理モデルは地質構造の発達史から作成することができ，面 の形状は地質体の露頭位置や走向傾斜にもとづいて決定す る.面の形状は，一般的に露頭位置や走向傾斜をXYZの 座標デー夕に変換し，これらを補間する事によって推定さ れる。したがって, 調査結果のデー夕量が少ない場合は, 時間と労力的に容易に変換することが出来るが境界面の推 定精度は悪くなり，反対に調査結果のデー夕量が多い場合 には，時間や労力的に容易に変換することが出来ないが推 定精度が向上するといった特徵が存在する。本研究では， 大量のデータが存在しても容易に三次元地質モデルを構築 できるように，地質構造の論理モデル(塩野ほか;1998)を用 いた露頭データやボーリングデータから境界面を推定する ためのデータを作成するプログラム『Georiginer』の開発 を行った。本研究で開発したプログラムを用いて出力した XYZ の座標デー夕を境界面推定プログラム Horizon2000(塩 野ほか;2001)に入力することによって，容易に境界面を作 成することができる。また，作成される地質境界面は三次 元地質モデルの構築に活用できる。

\section{5 年 3 月 4 日受付, 2005 年 10 月 20 日受理}

Geoinforum2004（2004 年6月,大阪）で一部講演.

* 大阪市立大学大学院理学研究科（現 株式会社建設技術研究所） Sumiyoshi-ku, Osaka 558-8585, Japan. E-mail: kajiyama@ctie.co.jp

** 日本技術開発株式会社 Japan Engineering Consultants Co., Ltd 5-6-10 Toyosaki, kita-ku, Osaka 531-0072, Japan

***大阪市立大学大学院理学研究科 Graduate School of Science, Osaka City University, 3-3-138 Sugimoto, Sumiyoshi-ku, Osaka 558-8585, Japan. 


\section{2. プログラムの基本原理}

本プログラムの基本原理は, 塩野ほか(1998)において提 案されている地質構造の論理モデルを用いたデータ処理方 法をもとにしている．ここでは，プログラムの説明を行う 前に，塩野ほか(1998)に基づいて地質構造の論理モデルの 説明を行い，地質構造の論理モデルを用いた三次元地質モ デルの構築方法の概略を示す.

\section{1 地質構造の論理モデル}

地質調査の対象となる三次元空間を $\Omega$ とし，空間 $\Omega$ には 原点 $\mathrm{O}$, 水平東向きに $x$ 軸, 水平北向きに $y$ 軸, 鉛直上向 きに $z$ 軸を持つ直角座標系 $\mathrm{O}-x y z$ が設定されているものとす る。また，空間 $\Omega$ を上に 2 分割する面 $S$ があるとき， $\Omega$ の中の面 $S$ より上側にあって $S$ を含まない空間を $S^{+}$とし, 空間 $\Omega$ のかで $S$ よ下側にあって $S$ を含む空間を $S^{-}$で表 すこととする。本論文では, 空間 $\Omega$ 内の任意の点を $Q\left(x_{q}\right.$, $\left.y_{q}, z_{q}\right)$ とし, 空間 $\Omega$ を上下に二分する面 $S$ が $z=s(x, y)$ のよう な一価関数で表されているとする。このとき， $S^{+}$と $S^{-}$を それぞれ，次のように表せるものとする(塩野ほか;1998). (第 1 図)

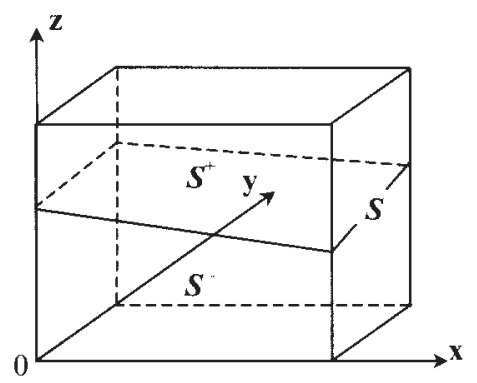

第 1 図 空間 $\Omega$ を 2 分割する面.

面 $S$ によって空間が $S^{+}$の部分空間と $S^{-}$の部分空間に分けられる. 面 $S$ は S-に含まれる。

$$
\begin{aligned}
& S^{+}=\left\{Q\left(x_{q}, y_{q}, z_{q}\right) \mid z_{q}>s\left(x_{q}, y_{q}\right)\right\} \\
& S^{-}=\left\{Q\left(x_{q}, y_{q}, z_{q}\right) \mid z_{q} \leqq s\left(x_{q}, y_{q}\right)\right\}
\end{aligned}
$$

また，この定義によれば $S^{+}$と $S^{-}$の間に次の関係が常に成 り立つ。

$$
\begin{aligned}
& S^{+} \cup S^{-}=\Omega \\
& S^{+} \cap S^{-}=\phi(\text { 空集合 })
\end{aligned}
$$

三次元空間 $\Omega$ は, 地表より下側にある地層や岩体からな る地質空間と地表より上側にある大気や水からなる上部空 間で構成される。地質空間を構成する地層や岩体は，あら かじめ三次元地質モデル上に表現される単位に区分されて いるものとし, 個々の地質単位が分布する領域を $b_{1}, b_{2}, \cdots$, $b_{n}$, 上部空間を $\alpha$ で表す。本文では，対象とする空間 $\Omega$ を 構成する単位という意味で $\alpha, b_{1}, b_{2}, \cdots, b_{n}$ を地質体とよぶ.

第 2 図のような地質境界面 $S_{1}, S_{2}$ と地質体 $\alpha, b_{1}, b_{2}$, の関係 は，次のように表すことができる。

$$
\begin{aligned}
& b_{1}=S_{1}{ }^{-} \cap S_{2}{ }^{-} \\
& b_{2}=S_{1}{ }^{+} \cap S_{2}{ }^{-} \\
& \alpha=S_{2}{ }^{+}
\end{aligned}
$$

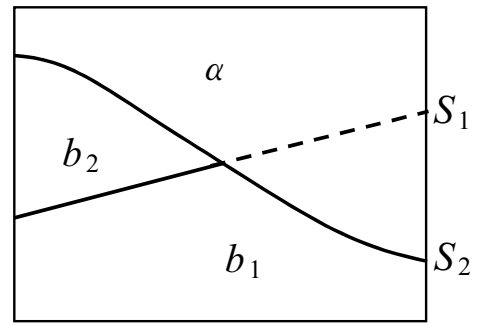

第 2 図 境界面 $S_{1}, S_{2}$ によって境される地質体 $\alpha, b_{1}, b_{2}$ の分布域.

このとき，式(2.5)は， $b_{1}$ が $S_{1}$ より下で $S_{2}$ より下の領域に 位置し， $b_{2}$ が $S_{1}$ より上で $S_{2}$ より下の領域に位置し， $\alpha$ が $S_{1}$ と無関係で $S_{2}$ より上の領域に位置するということを示す. ここで， $\alpha$ が $S_{1}$ と無関係というのは， $S_{1}$ の面の形状に左右 されず， $S_{2}$ の形状のみによって領域が定義されることを示 す。無関係を式において表現する必要がある場合，境界面 $S_{1}$ をもちいて $S_{1}^{0}$ と表す事とする。この表現方法を用いた 場合，式(2.5)は以下のように表現できる.

$$
\begin{aligned}
& b_{1}=S_{1}{ }^{-} \cap S_{2}{ }^{-} \\
& b_{2}=S_{1}{ }^{+} \cap S_{2}{ }^{-} \\
& \alpha=S_{1}{ }^{0} \cap S_{2}{ }^{+}
\end{aligned}
$$

また，式(2.5)で表される地質構造の論理モデルは第 1 表の ように表形式で表すことができる．表形式は以下の表記方 法で記載される。

(1)1列目に地質体名を表記する.

(2)1行目から上部空間を表記する.

(3)上部空間の表記後，次行に境界面を表記する。

(4)境界面の表記後，次行に地質体を表記する。

(5) 2 列目以降に地質体と境界面の関係を+,一,空白を表 記する。

第 1 表 第 3 図の地質構造に対応した地質構造の論理モデル

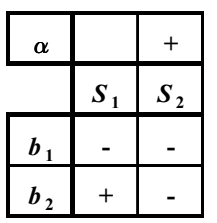

地質構造の論理モデル；1列に地質体名を表記，上部空間と地質 空間の間に境界面名を表記，2列目以降に地質体と境界面の関係 を+,一,空白を用いて記述

このように，地質体 $\alpha, b_{1}, \cdots, b_{n}$ を面 $S_{1}, \cdots, S_{p}$ を用いて対 象とする空間 $\Omega$ の部分領域として定義できる。このような 地質体の分布域と境界面の論理的関係を Shiono et al.(1994), 塩野ほか(1998)は「地質構造の論理モデル」と呼んだ。こ の地質構造の論理モデルの構築手法として，塩野ほか(1998) は堆積作用と侵食作用をモデル化することで，それぞれの 作用に対応した漸化式モデル(event $\left.c, r, c^{*}\right)$ を導き, 漸化式 モデルを用いる方法を提案している。

\section{2 地質構造の論理モデルを利用した境界面の位置決定}

地質構造の論理モデルは，地質体の分布域と面の論理的 
関係を表している。この論理的関係を利用することによっ て, 野外調査デー夕(露頭地点)から境界面の形状を決定す るデータの作成を行うことができる.

ここでは，プログラムが扱う地質構造の論理モデル内の 上部空間と $n$ 個の地質体 $\left(\alpha, b_{1}, b_{2}, \cdots, b_{n}\right)$ が $p$ 枚の境界面 $\left(Y_{1}\right.$, $\left.Y_{2}, \cdots Y_{p}\right)$ によって次式のように，すべて単項式で表現され る場合に限定する。

$$
Y_{1} \cap Y_{2} \cap \cdots \cap Y_{p} \quad\left(Y_{k}=S_{k}{ }^{+}, S_{k}^{-} \text {または } S_{k}^{0}(k=1, \cdots, p)\right)
$$

いま，野外調査デー夕のある露頭地点 $o_{i}$ において任意の地 質体 $b_{j}(j=1, \cdots, n)$ が分布しているものとし, その地質体が 次の式で表されているとする。

$$
b_{j}=Y_{1} \cap Y_{2} \cap \cdots \cap Y_{p}
$$

このとき, 露頭地点 $o_{i}$ 内の任意の点 $Q\left(x_{q}, y_{q}, z_{q}\right)$ に対して次 式が成り立つ.

$$
Q\left(x_{q}, y_{q}, z_{q}\right) \in Y_{1} \cap Y_{2} \cap \cdots \cap Y_{p}
$$

したがって，面 $S_{k}(k=1, \cdots, p)$ に関して次の事が言える

(1) $Y_{k}=S_{k}^{-}$のとき, $S_{k}$ は $Q$ の上側を通る.

(2) $Y_{k}=S_{k}+$ のとき, $S_{k}$ は $Q$ の下側を通る.

(3) $Y_{k}=S_{k} 0$ のとき, $Q$ は $S_{k}$ と無関係である.

己れは, 各境界面 $S_{k}$ が各々 $z=s_{k}(x, y)$ で表されている場 合， $s_{k}(x, y)$ に関して次のような不等式制約条件を与えるこ とを意味する。

$$
\begin{aligned}
& Y_{k}=S_{k}^{-} \text {のとき, } z_{q} \leqq s_{k}\left(x_{q}, y_{q}\right) \\
& Y_{k}=S_{k}+\text { のとき, } z_{q} \geqq s_{k}\left(x_{q}, y_{q}\right)
\end{aligned}
$$

たとえば，対象とする調査地域の地質構造の論理モデル が第 2 表の通りであり，地質構造が第 3 図に示すものであ ったとする。点 $\mathrm{A}$ を露頭とし，この露頭の座標值を $\mathrm{A}\left(x_{a}\right.$, $\left.y_{a}, z_{a}\right)$ とする.この露頭 $\mathrm{A}$ に地質体 $b_{2}$ が露出していたとす ると, 地質構造の論理モデルから以下の関係が成り立つ.

$$
\mathrm{A}\left(x_{a}, y_{a}, z_{a}\right) \in S_{1}^{+} \cap S_{2}^{-} \cap S_{3}^{-}
$$

この式から，境界面 $S_{1}$ は点 $\mathrm{A}\left(x_{a}, y_{a}, z_{a}\right)$ より下側(すなわち $\left.z_{a} \leqq s_{1}\left(x_{a}, y_{a}\right)\right)$ を通り, 境界面 $S_{2}$ は点 $\mathrm{A}\left(x_{a}, y_{a}, z_{a}\right)$ 地点より上

第 2 表 第 4 図の地質構造に対応した地質構造の論理モデル
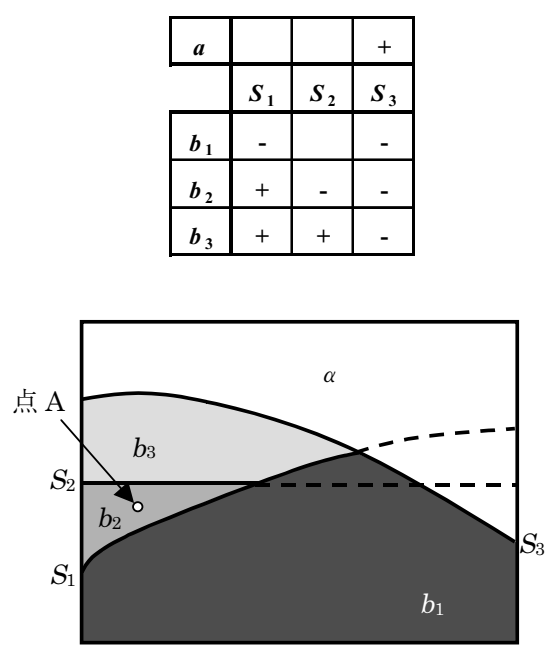

第 3 図 第 1 表の論理モデルに対応した地質構造の例
側(すなわち $\left.z_{a} \geqq s_{2}\left(x_{a}, y_{a}\right)\right)$ を通り，境界面 $S_{3}$ は $\mathrm{A}\left(x_{a}, y_{a}, z_{a}\right)$ 地 点より上側(すなわち $\left.z_{a} \geqq s_{3}\left(x_{a}, y_{a}\right)\right)$ を通るという情報を与え ることができる。

すべての野外調査データに対してこのような制約条件を 整理すると，各境界面に面が満たすべき制約条件のセット を得ることができる。

\section{3 地質構造の論理モデルを用いた三次元地質モデリング} 塩野ほか(1998)が提案している地質構造の論理モデルを用 いて，野外踏査デー夕，ボーリングデー夕などの地質デー 夕から三次元地質モデルの構築と可視化を行うためには, 以下の 5 つの作業を行う必要がある。作業の流れを第 4 図 に示す。

\section{(1)地形の DEM (Digital Elevation Model) 化} 地形図などのデータから STRIPE 法(Noumi;2003)などの DEM 作成法を利用してDEMの作成を行う。レーザープ ロファイラーのデータや国土地理院発行の数值地図の使 用もできる。

\section{(2)論理モデルの構築}

地質調査データをもとに地質体と境界面の関係を導き, 対象地域の地質構造の論理モデルを構築する。地質構造 の論理モデルの構築については塩野ほか(1998)を参照さ れたい.

(3)位置データの作成 地質構造の論理モデルの特徴を利用して, 地形データ, 野外調査デー夕，地質構造の論理モデルを利用すること によって, 地質境界面を推定するための XYZ座標形式 の位置デー夕(不等式標高データ・等式データ)の作成を行 j.

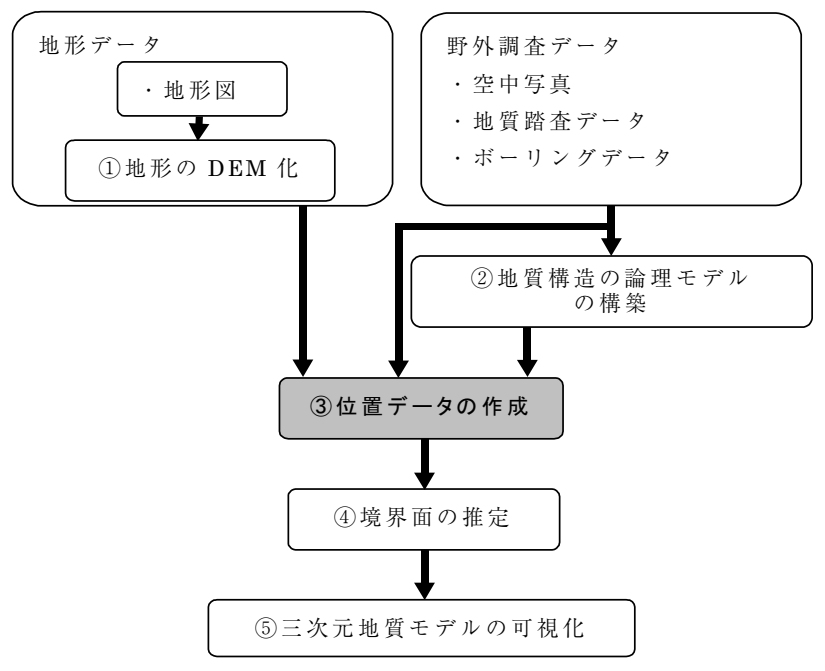

第 4 図 三次元地質モデル構築の流れ

位置デー夕は地形デー夕, 野外調査デー夕, 地質構造の論理モデ ルの 3 つから作成され, 三次元地質データは地形データ, 境界面 データ，地質構造の論理モデルから作成される. 
(4)地質境界面の推定

(3)で作成したそれぞれのデー夕を不等式制約条件付きの データから境界面の推定を行えるHorizon2000(塩野ほ か;2001)などのソフトウェアを利用して，それぞれの地 質境界面(DEM)の推定を行う。

\section{(5)三次元地質モデルの可視化}

(1),(4)で作成した地形面と地質境界面と(2)の地質構造の論 理モデルを用いて, 升本ほか(2004)や米澤ほか(2004)に よって提案されている手法などを用いて三次元地質モデ ルの可視化を行う.

本研究で開発したプログラムは，第 4 図に示すフローチ ヤート内の『位置データの作成』の部分を行うものであ る.

\section{3. プログラムについて}

本プログラムは Fortran77 コンパイラーに対応した言語で 記述されており，OSをUnix ベースとする Redhat-Fortran77， Unix-Fortran77 において動作を確認している。プログラム に入力するデータは地質構造の論理モデル, 地形標高デー 夕 (DEM), 地質調査データであり, 境界面推定プログラム Horizon2000(塩野ほか;2001)の入力形式にしたがったデー夕 ファイルが出力される。このプログラムは, 地質構造の論 理モデルが以下の条件を満たす場合にかぎり使用する事が できる。

(1)境界面を $S_{k}(k=1, \ldots, p)$ としたとき， $S_{k}$ によって上部空間 と地質空間が分けられている。

(2)地質構造の論理モデルの地質体が単項式で表現されてい る.

\section{1 入力データ}

プログラムに入力するデータを地質調査データなどから

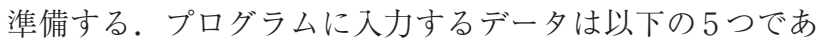
り，これらのデータのうち(1)〜(3)は必ず入力しなければな らない。(4),(5)のデー夕は必ずしも必要ではない.

(1)地質構造の論理モデルファイル

(2)データ分布ファイル

(3)地形データファイル

(4)ポイントデータファイル

(5)走向傾斜データファイル

以下，それぞれのデータファイルの形式について説明す る.

\section{(1)地質構造の論理モデルファイル}

地質構造の論理モデルファイルは, 表形式で表された地 質構造の論理モデルを使用する。また，第 1 表と第 2 表の ように，地質体と境界面の関係を表す記号が $(+,-$, , 空欄 $)$ で表されている場合，十のときは $1,-$ の時は -1 に変更し 空欄の場合は 0 と表記し直す。地質体 $\alpha, b_{1}, \ldots b_{i}(i=, 1, \ldots$, n)は色で区別し，地質体の色の指定はプログラムで使用さ れる色指定方法で行う。本プログラムでは色の成分 RGB にそれぞれ 0 ～ 255 までの数值(成分の值)を代入することに よって行った，Rは赤成分， $\mathrm{G}$ は緑成分，B は青成分であ る。このデータファイルで指定した色は, 以降のデータと の関連づけに使用される。

データの形式を第 5 図に例示する。このデータは第 2 表 に示す地質構造の論理モデルをプログラムの入力形式に変 更したものである。デー夕構造は, 境界面の数と各地質体 のデー夕から構成される。1行目が境界面の数であり, 2 行目以下は各地質体のデータであり, 地質体の数だけ必要 となる.

地質体のデー夕は，地質体に対応した色データ(1列目か ら 3 列目)と境界面と地質体の関倸(4列目以降)から構成され ている。色デー夕は色の成分值であり，1列目は赤成分の 濃度值，2列目は緑成分の濃度值，3列目は青成分の濃度 值である。ただし，上部空間の色成分データはすべて0 と する。また，境界面と地質体の関係は， $1,-1,0$ の值で表 す。たとえば，図中の 3 行目のデー夕は以下のことを示し ている.

- 地質体に対応した色として, 赤色成分の濃度値 255, 緑 成分の濃度值 0 , 青成分の濃度值 0 が使用されている. この情報を(R:255, G:0, B:0)の形式表すこととする.

- 地質体 $b_{1}$ は， $S_{1}$ の下側に領域で，かつ $S_{3}$ の下側の領域 に分布しており， $S_{2}$ には無関係である。

\begin{tabular}{|cccccc|}
\hline 3 & & & & & \\
0 & 0 & 0 & 0 & 0 & 1 \\
255 & 0 & 0 & -1 & 0 & -1 \\
255 & 255 & 0 & 1 & -1 & -1 \\
0 & 128 & 0 & 1 & 1 & -1 \\
\hline
\end{tabular}

第 5 図 地質構造の論理モデルの入力ファイル形式 1 行目は境界面の数. 2 行目以降が地質構造の論理モデル. $1 \sim 3$ 列目は地質体に対応した色 (1列目はR，2列目は $\mathrm{G} ， 3$ 列目はBの 色值 (256 階調の階調番号). 4 列目以降が境界面と地質体の関係 $(1$, $-1,0)$. 形式的に上部空間の RGB の值にはすべて 0 とする.

\section{(2)データ分布ファイル}

データ分布ファイルは, あらかじめ地質体分布, ポイン トデー夕, 走向傾斜デー夕などのデー夕分布図を作成して おき，それをPaintshop Pro 7を用いてフルカラーのEPS 形 式に変換した画像デー夕を使用する。他のソフトを用いて EPS 形式で保存したものを使用する場合は，データのヘッ ダーが保存するソフトによって変わるため, プログラムの デー夕読み取り部分の変更が必要となる。データ分布ファ イルの作成は，それぞれ以下の法則に従って色塗りされた ものを使用する，色塗りするもとの画像は，地形図などを スキャニングし，指定した色と同じ值が画像上に残らない ようにするために，2值化を行ったデー夕を用いる.

(1)地質体分布

露頭などにおいて地質構造の論理モデルの地質体に相 
当する地層が確認された場合，あるいは既存の地質図を 活用する場合などに使用する。デー夕分布図上にペイン ト系の画像処理ソフトを利用して，地質体の分布が確認 された地点(露頭位置など)に，(1)の地質構造の論理モデ ルファイルで指定を行った地質体に対応した色(RGB 值) をそれぞれ着色する。

\section{(2)ボーリング地点などのポイントデータ}

ボーリング地点などの 1 地点にいくつもデータがある 場合などに使用する。画像上で位置デー夕のある地点ご とに異なる色(RGB 值)を使用する。ただし，(1)で使用し た色(RGB 值)とは異なる色を使用しなければならない. ここで指定した色は，(4)のポイントデータファイルと関 連づけられる。

\section{(3)走向傾斜データ}

走向傾斜のデー夕を入力する場合に使用する。このデ ー夕も(2)の位置デー夕と同様に，画像上で地点ごとにそ れぞれ異なる色(RGB 值)を使用する。ただし，(1),(2)で使 用している色( RGB 值)とは異なる色を使用しなければな らない。ここで指定される色は，(5)の走行傾斜データフ アイルと関連づけられる。

\section{(3)地形データファイル}

(2)のデータ分布図と同じ領域の地形データをDEM とし て使用する。この地形データは，レーザープロファイラー などによって計測されたデータもしくは地形図から STRIPE 法(Noumi;2003)などを用いて作成した高精細な地形デー夕 を用いることが望ましい.

入力データの形式は，STRIPE法で使用される Horizon2000(塩野ほか;2001)の出力形式をそのまま入力でき るように, Horizon2000の出力形式と同じにした(第 6 図). 各データはアスキー形式で並べられており，1行目はヘッ ダー, $x, y$ 方向の格子数 $\left(N_{x}, N_{y}\right)$, 基準座標值 $\left(X_{\min }, Y_{\min }\right), x, y$ 方向の格子間隔 $\left(D_{x}, D_{y}\right)$ であり, 2 行目以下が Horizon 2000 によって計算された標高データが表記されている。

\section{(4)ポイントデータファイル}

ポイントデータファイルは，1つの地点に何点もデータ が存在する場合や露頭地点が地下に存在する場合などに使

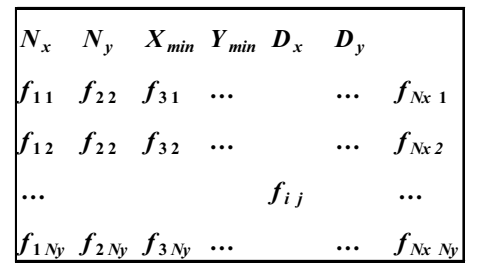

第6図＼cjkstart地形データの入力ファイル形式 本形式は, Horizon2000(塩野ほか(2001))の出力形式に準じており, 各データはアスキー形式で並ベられている。1行目はヘッダー部. $x, y$ 方向の格子数 $\left(N_{x}, N_{y}\right)$. 基準座標值 $\left(X_{\min }, Y_{\min }\right) . x, y$ 方向の格子間 隔 $\left(D_{x}, D_{y}\right)$. 2 行目以下がHorizon2000によって計算された標高.
用する。このデータがない場合は，入力する必要がない. 入力の形式は, 次の構成になる.

(1)各レコードは 7 項目で構成される

(2)最初の 3 項目は，(2)で作成したデータ分布ファイルの位 置デー夕であり，(2)で指定した色の成分 $(\mathrm{RGB})$ をそれぞ れ Rの值， $\mathrm{G}$ の值， $\mathrm{B}$ の值の順で並べたものである.

(3) 4 項目はデータが存在する位置の標高值である.

(4) 5-7 項目は地質体の色情報で，(1)で作成した地質構造の 論理モデルファイルの地質体で指定した色成分(RGB)を それぞれ Rの值， $\mathrm{G}$ の值，Bの值の順で並べたものであ る.

たとえば，第 7 図のようなポイントデータを作成した場合， 1 行目のデータは次のことを示す.

(1)ポイントデータの位置は, 色が(R:128,G:0,B:128)の地点 である。

(2)データの標高值が $100 \mathrm{~m}$ である.

(3)その位置には, 色が(R:255,G:0,B:0)に対応した地質体が 分布する。

この形式で地質境界を入力する場合は，1つの地点に $2 つ$ の地質体が存在すると解釈して作成する。たとえば，地質 境界の標高が $h$ ，デー夕分布図の色が $\left(\mathrm{R}_{1}, \mathrm{G}_{1}, \mathrm{~B}_{1}\right)$ ，境界に分 布する地質体に対応する色が $\left(\mathrm{R}_{2}, \mathrm{G}_{2}, \mathrm{~B}_{2}\right)$ と $\left(\mathrm{R}_{3}, \mathrm{G}_{3}, \mathrm{~B}_{3}\right)$ の場合, 次のようなデー夕を作成する.

$$
\begin{aligned}
& \mathrm{R}_{1} \mathrm{G}_{1} \mathrm{~B}_{1} h \mathrm{R}_{2} \mathrm{G}_{2} \mathrm{~B}_{2} \\
& \mathrm{R}_{1} \mathrm{G}_{1} \mathrm{~B}_{1} h \mathrm{R}_{3} \mathrm{G}_{3} \mathrm{~B}_{3}
\end{aligned}
$$

\begin{tabular}{|ccccccc|}
\hline 128 & 0 & 128 & 100 & 255 & 0 & 0 \\
128 & 0 & 128 & 100 & 255 & 255 & 0 \\
128 & 0 & 128 & 150 & 255 & 0 & 0 \\
$\cdots$ & $\ldots$ & $\ldots$ & $\ldots$ & $\ldots$ & $\cdots$ & \\
0 & 0 & 255 & 138 & 255 & 255 & 0 \\
0 & 0 & 255 & 138 & 0 & 128 & 128 \\
\hline
\end{tabular}

第7図 ポイントデータの入力ファイル形式 $1 \sim 3$ 列目はデー夕分布図に対応する RGB の色值 (1 列目は R, 2 列目は G, 3列目は B の色值 (256 階調の階調番号))。4列目は分布 する標高值. 5〜 7行目は地質構造の論理モデル内の地質体に対応 する $\mathrm{RGB}$ の色值 $(5$ 列目は R，6列目は $\mathrm{G} ， 7$ 列目は $\mathrm{B}$ の色值 $(256$ 階調の階調番号))とする。

\section{(5)走向傾斜データファイル}

走向傾斜データファイルは，地質境界や断層などの走向 傾斜のデータを入力する場合に使用する。このデータがな い場合は入力する必要はない。入力の形式は次の構成にな る。

(1)各レコードは 6 項目で構成される

(2) 1 項目は(1)の地質構造の論理モデルファイル内の境界面 $\left(S_{1}\right.$ であれば $1 ， S_{2}$ であれば 2$)$ の数字である.

(3) 2-4 項目は，(2)で作成したデータ分布ファイルの走行傾 斜デー夕であり，(2)で指定した色の成分 $(\mathrm{RGB})$ をそれぞ れ Rの值， $\mathrm{G}$ の值， $\mathrm{B}$ の值の順で並べたものである.

(4) 5 項目は北から時計回りにはかった傾斜の方位角(傾斜方 位)の值である。 


\begin{tabular}{|cccccc|}
\hline 1 & 200 & 0 & 200 & 130 & 40 \\
1 & 128 & 0 & 200 & 170 & 35 \\
2 & 128 & 255 & 128 & 150 & 70 \\
& $\ldots$ & $\ldots$ & $\ldots$ & & \\
2 & 135 & 135 & 0 & 20 & 35 \\
2 & 150 & 150 & 0 & 270 & 50 \\
\hline
\end{tabular}

第 8 図 走向傾斜データの入力ファイル形式 1 列目は指定する境界面. 2 ４列目はデー夕分布図に対応する RGB の色值(1列目は R, 2列目は G, 3列目は B の色值(256 階調の 階調番号)). 5 列目は走向(方位角表記). 6 行目は傾斜角とする。

(5) 6 項目は傾斜角の值である.

たとえば，第 8 図のような走向傾斜データを作成した場 合，1行目のデータは次のことを示している.

(1)境界面 $S_{1}$ の走向傾斜データである.

(2)走向傾斜データの位置は, 色が (R:200,G:0,B:200)の地点 である。

(3)傾斜方位が 130 度である.

(4)傾斜が 40 度である.

\section{2 出力データとその形式}

本プログラムによって出力されるファイルは以下の 2 つからなる。

(1)不等式制約条件ファイル

(2)走向傾斜ファイル

\section{(1)不等式制約条件ファイル}

不等式制約条件ファイルのデータ形式は，第 9 図に示す 形式であり, Horizon2000(塩野ほか;2001)や Terramod 2001(坂本ほか;2001)にそのまま入力できるように出力ファ イル形式をHorizon2000の入力形式と同じにした。等式 · 不等式制約条件のファイルは, 左列より, ID 番号, $x$ 座 標, $y$ 座標, $z$ 座標, 地点と境界面の関係 $(+1$ または -1 (不 等号の向き))がアスキーファイル形式で並べられる. ID 番 号は, 1 からデータの数に準じた番号がつけられる. 地点 と境界面の関係は, +1 の場合は境界面がその地点より上

\begin{tabular}{|rcccc|}
\hline 1 & 50 & 0 & 121 & -1 \\
2 & 50 & 50 & 130 & -1 \\
3 & 50 & 100 & 136 & -1 \\
$\cdots$ & $\ldots$ & $\ldots$ & $\ldots$ & \\
15152 & 4500 & 3850 & 50.6 & -1 \\
15153 & 4500 & 3900 & 45.9 & 1 \\
\hline
\end{tabular}

第9図 不等式制約条件ファイルの出力形式 本形式は, Horizon2000(塩野ほか;2001)の入力形式に準じており, 各データはアスキー形式で並べられている．1列目はデータの ID 番号. 2 行目はXの座標值. 3 行目は $\mathrm{Y}$ の座標值, 4 行目は $\mathrm{Z}$ の座 標值. 5 行目は座標と境界面の関倸 $(0$ : 境界面が座標值を通る。 1 : 境界面が座標值より下側に位置する。 1 ：境界面が座標值より 上側に位置する)
側を通ることを示し，-1 は境界面がその地点より下側を 通ることを示し，0は境界面がその地点を通ることを示す。 たとえば，第 9 図の 1 行目のデータの場合，ID番号が $1, x$ 座標が $50, y$ 座標が $0, z$ 座標が 12 , 境界面がこの座標より も下側に存在するということを示す。出力されるファイル は，地質構造の論理モデルにおいて記述されている境界面 (地形面を除く)のすべてに対してデータファイルが自動的に 作成される。

\section{(2)走向傾斜ファイル}

走向傾斜ファイルのデータ形式は, 第 10 図に示す形式 であり，このデータも不等式条件ファイルと同様に Horizon2000 や Terramod2001にそのまま入力できるように Horizon 2000 の入力形式と同じにした. 走向傾斜ファイル は, 左列より, ID 番号, $x$ 座標, $y$ 座標, $z$ 座標, 傾斜方位 $\phi$, 傾斜角 $\theta$ がアスキーファイル形式で並べられる。たと えば，第 10 図の 1 行目のデータの場合, ID 番号が $1, x$ 座 標が $125, y$ 座標が $250, z$ 座標が 121 , 傾斜方位が $150^{\circ}$, 傾斜角が $30^{\circ}$ ということを示す. 走向傾斜データの存在す る境界面のみファイルが作成される。

\begin{tabular}{|llllll|}
\hline 1 & 125 & 250 & 121 & 150 & 30 \\
2 & 300 & 450 & 130 & 250 & 60 \\
\hline
\end{tabular}

第10図 走向傾斜ファイルの出力形式 本形式は, Horizon2000(塩野ほか;2001)の入力形式に準じており, 各データはアスキー形式で並ベられている。1列目はデータのID 番号. 2 行目はXの座標值. 3 行目はY の座標值, 4 行目は Z の座 標值. 5 行目は北から時計回りに傾斜角の方位を計った值(傾斜方 位). 6 行目は傾斜角.

\section{3 プログラム内のデータ処理}

本プログラムは, 以下の処理アルゴリズムの階層構造を 利用して出力ファイルの作成を行う。ただし, $(i, j)$ は画像 のピクセルの位置とし, $(x, y, z)$ は実際の位置情報を表す。

(1)データの読み込み

(2)地質構造の論理モデルの境界面数だけ(3)の操作を繰り返 す.

(3)データ分布ファイルの位置 $(i, j)$ の範囲すべての点に対し て(3)-1〜(3)-3の操作を行う.

(3)-1 データ分布ファイル内でデータのある場所に対し て(3)-1-(a)〜 (3)-1-(b)の処理

(3)-1-(a) RGB值が地質体に対応した值の場合

i）地質構造の論理モデルファイル内で, データ分布 ファイルで見つかったRGB值を検索する。

ii）検索された地質体と境界面の関係を調べる.

iii) 関係が無関係(0)の場合：データとしない. 関係が十の場合(1)の場合：1=-1とおき，iv)に進 む.

関係がーの場合 $(-1)$ の場合 : $1=1$ とおき, iv)に進 む.

iv)データの位置 $(x, y, z)$ のうち, $(x, y)$ はデータ分布ファ 
イルの位置 $(i, j)$ から計算する。 $z$ は地形データの線 形補間で求める.

v) データを ID $, x, y, z, l$ の形式で出力する.

(3)-1-(b) RGB 值がポイントデータに対応した值の場合

i) ポイントデータファイル内で, データ分布ファイ ルで見つかったRGB值を検索する。

ii）見つけたポイントデータに対応する地質体を地質構 造の論理モデルファイルを用いて調べる。

iii）地質構造の論理モデルファイル内の対応する地質 体と作成中の境界面の関係を調べる。

iv) 関係が無関係(0)の場合：データとしない.

関係が+の場合(1)の場合：1=-1とおき，iv)に進 む.

関係がーの場合 $(-1)$ の場合：1＝1とおき，iv)に進 む.

iv) データの位置 $(x, y, z)$ のち, $(x, y)$ はデータ分布ファイルの位置 $(i, j)$ から計算す る.

$z$ はポイントデータ内の值を使用する.

v）データを ID $, x, y, z, l$ の形式で出力する.

(3)-2 RGB 值が走向傾斜デー夕に対応した值の場合

i）走向傾斜データファイル内で，データ分布ファイ ルで見つかったRGB值を検索する。

ii）見つけた走向傾斜データに対応する境界面情報を調 ベる。

iii) 境界面情報と作成する境界面が一致する場合：iv） に進む 境界面情報と作成する境界面が一致しない場合：デ ータとしない

iv) デー夕の位置 $(x, y, z)$ のうち, $(x, y)$ はデー夕分布フ アイルの位置 $(i, j)$ から計算する。 $z$ は地形データの 線形補間で求める.

v）データを ID $, x, y, z, \phi, \theta$ の形式で出力する.

(3) -3 データ分布図の範囲の検索終了時にファイルの出力

\section{4 プログラムの使用方法}

本プログラムの使用方法を実行時にキーボードから入力 する順に説明する。下線部分をキーボードから入力する.

(1)地質構造の論理モデルファイルの入力

プログラムの実行後,

Input Logical model of geologic structure $=$

で地質構造の論理モデルファイルのファイル名を入力する.

\section{(2)データ分布ファイルの入力}

地質構造の論理モデルファイルの入力後,

Input field data filename $=$

でデータ分布ファイルのファイル名を入力する。

\section{(3)地形データの入力}

データ分布ファイルの入力後,
Input elevation data filename

で地形データファイルのファイル名を入力する.

(4)ポイントデータの入力

地形データファイルの入力後, ポイントデータファイル があるかないかを

Do you have point data?

1 (point data) or 2 (no point data) =

で選択する。ポイントデータファイルがある場合は 1 ，な い場合は 2 を入力する。

さらに,

Input point data filename

でポイントデータファイルのファイル名を入力する.

\section{(5)走行傾斜データファイルの入力}

(3)の作業の終了後，走向傾斜データファイルがあるかな いかを

Do you have strike dip data?

1 (strike dip) or 2 (no strike dip) =

で選択する．走向傾斜データファイルがある場合は 1 ，な い場合は 2 を入力する.

さらに,

Input point data filename

で走向傾斜データファイルのファイル名を入力する.

\section{(6)ファイルの自動出力}

(5)の作業終了後，地質構造の論理モデルファイルにおい て記述されているすべての境界面(地形面を除く)のデータが 自動的に作成される.

\section{4. プログラムの実行例と三次元地質モデリング}

本章では，プログラムへ入力するデータ作成とそれらを 用いた三次元地質モデルの構築方法を説明する. データの作成は以下の手順に従って行う。

\section{(1)地質構造の論理モデルファイルの作成}

調査結果のデー夕などから境界面と地質体の論理的関係 を考え, 地質構造の論理モデルの構築を行う。堆積作用 · 侵食作用のみによって形成される場合は，塩野ほか(1998) の漸化式モデルを用いることによって，地質構造の論理モ デルの構築を行うことができる。

テストデータの対象は, 中央構造線の発達する和歌山県 北部の和泉山脈南麓地域である。本地域は，白亜系の和泉 層群からなる山地が直線状の断層崖を境にして段丘面群と 接しており，和泉層群と菖蒲谷層を接する北傾斜の低角逆 断層 (中央構造線)が推定されている。この地域に対応した 地質構造の論理モデルを第 11 図(a)に示す模式断面を基に構 築した (第 11 図(b))。和泉層群と菖蒲谷層の境界を $S_{1}$, これ らの地層と段丘層の境界を $S_{2}$, 地表面を $S_{3}$ とする。この地 質構造の論理モデルの地質体に対応する色をそれぞれ以下 


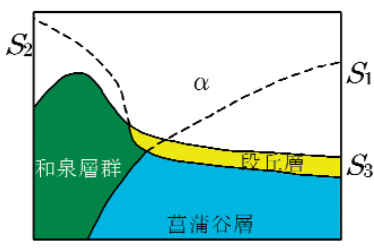

(a) テスト地域の地質構造

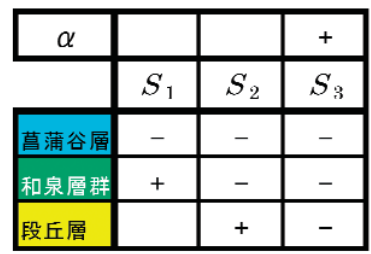

(b) 地質構造の論理モデル

\begin{tabular}{|cccccc|}
\hline 3 & & & & & \\
0 & 0 & 0 & 0 & 0 & 1 \\
128 & 128 & 255 & -1 & -1 & -1 \\
0 & 128 & 0 & 1 & -1 & -1 \\
255 & 255 & 0 & 0 & 1 & -1 \\
\hline
\end{tabular}

(c) 地質構造の論理モデルファイル

第11図 テストデータの地質構造の論理モデル

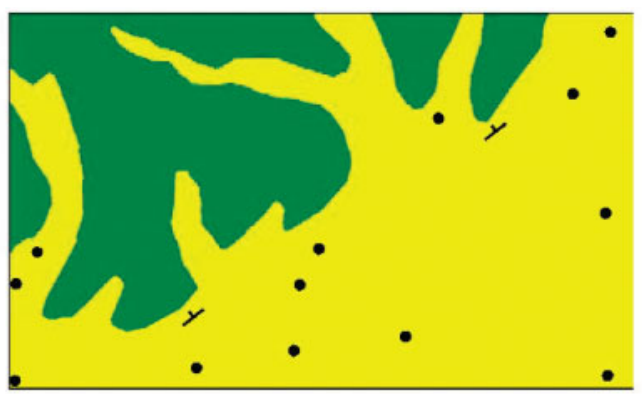

第 12 図 データ分布ファイル

緑は和泉層群の分布範囲. 黄色は段丘層の分布範囲.

ー夕位置. 走行傾斜マークは走行傾斜デー夕の位置.

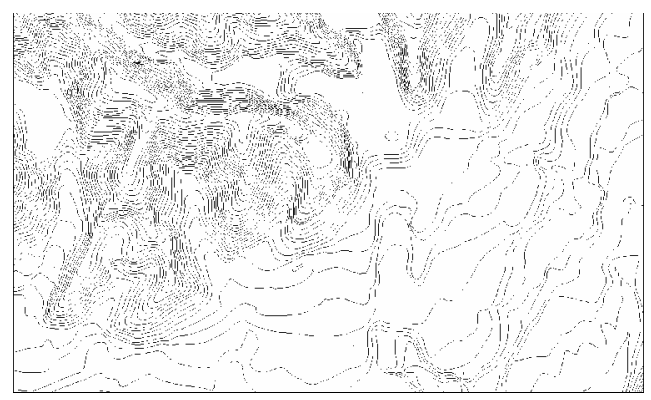

第 13 図 地形データファイル

STRIPE 法を使用して作成した地形データファイルであり，格子間 隔は $20 \mathrm{~m} ，$ 格子数は $150 * 101$ である。

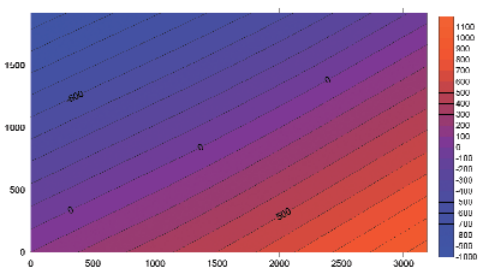

(a) 境界面 $S_{1}$

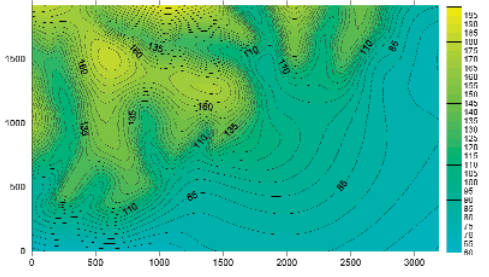

(b) 境界面 $S_{2}$

第 17 図推定を行った境界面 $S_{1}, S_{2}$

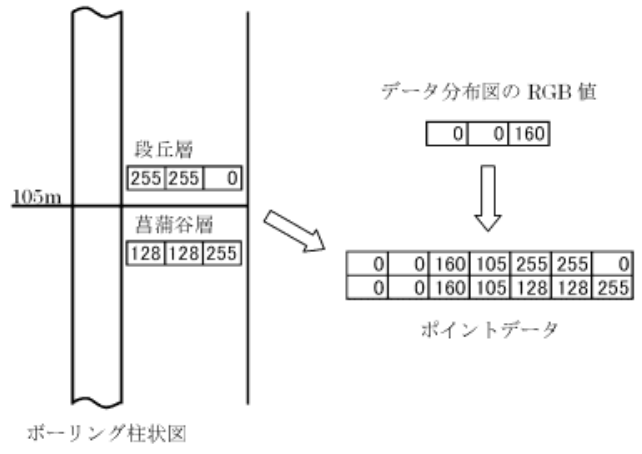

第 14 図 ポイントデータの作成方法

ボーリング地点がデータ分布図上の $(\mathrm{R}: 0, \mathrm{G}: 0, \mathrm{~B}: 160)$ ，ボーリングデ 一夕の標高 $105 \mathrm{~m}$ に扔いて菖蒲谷層(R:128,G:128,B:255) と段丘層 (R:255, G:255,B:0)の境界が存在する場合, デー夕分布図上の (R:0,G:0,B:160)を 1 3 行目，標高を 4 行目，分布する地質体の RGB 值を $5 \sim 7$ 行目に記述する。

\begin{tabular}{rrrrrrr|}
\hline 0 & 0 & 255 & 70 & 128 & 128 & 255 \\
0 & 0 & 255 & 70 & 255 & 255 & 0 \\
0 & 0 & 200 & 75 & 128 & 128 & 255 \\
0 & 0 & 200 & 75 & 255 & 255 & 0 \\
0 & 0 & 230 & 90 & 128 & 128 & 255 \\
0 & 0 & 230 & 90 & 255 & 255 & 0 \\
0 & 0 & 160 & 105 & 128 & 128 & 255 \\
0 & 0 & 160 & 105 & 255 & 255 & 0 \\
0 & 0 & 140 & 110 & 128 & 128 & 255 \\
0 & 0 & 140 & 110 & 255 & 255 & 0 \\
0 & 0 & 120 & 75 & 255 & 255 & 0 \\
0 & 0 & 120 & 75 & 128 & 128 & 255 \\
0 & 0 & 100 & 85 & 255 & 255 & 0 \\
0 & 0 & 100 & 85 & 128 & 128 & 255 \\
0 & 0 & 100 & 75 & 255 & 255 & 0 \\
0 & 0 & 100 & 75 & 128 & 128 & 255 \\
0 & 0 & 180 & 75 & 128 & 128 & 255 \\
0 & 0 & 180 & 75 & 255 & 255 & 0 \\
0 & 0 & 185 & 85 & 128 & 128 & 255 \\
0 & 0 & 185 & 85 & 255 & 255 & 0 \\
140 & 0 & 140 & 115 & 0 & 128 & 0 \\
140 & 0 & 140 & 115 & 255 & 255 & 0 \\
160 & 0 & 160 & 115 & 0 & 128 & 0 \\
160 & 0 & 160 & 115 & 255 & 255 & 0 \\
\hline
\end{tabular}

第 15 図 ポイントデータファイル

左から 1 ～行目はデー夕分布図上の RGB 值, 4 行目は境界面の 標高，5～7行目は分布する地質体の RGB 值である.

\begin{tabular}{|llllll|}
\hline 1 & 255 & 0 & 0 & 330 & 35 \\
1 & 128 & 0 & 0 & 335 & 30 \\
\hline
\end{tabular}

第 16 図 走向傾斜データファイル

左から 1 行目は境界面の番号, $2 \sim 4$ 行目はデー夕分布図上の RGB 值，5行目は傾斜方位，6行目は傾斜角である。

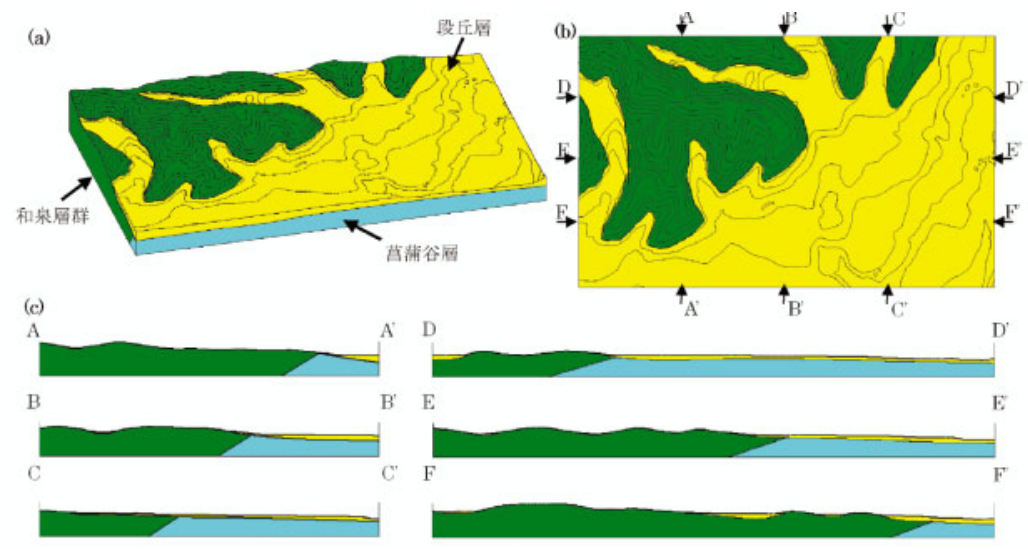

(a) 三次元地質モデルの鳥瞰図 (b) 三次元地質モデルの平面図 (c) 三次元地質モデルの断面図

第18図 Geomodel2003を用いた三次元地質モデルの可視化例 
のように設定した.

(1)菖蒲谷層は水色(R:128,G:128,B:255)とし，赤成分に 128 , 緑成分に 128 ，青成分に 255 の与えた.

(2)和泉層群は緑色(R:0,G:128,B:0)とし,赤成分に0, 緑成分 に128，青成分に0の值を与えた。

(3)丘層は黄色(R:255,G:255,B:0)とし，赤成分に255，緑成分 に255，青成分に0の值を与えた。

これらの作業をすることによって，第 11 図(c)に示す入力 データの作成を行った。

\section{(2)データ分布ファイルの作成}

地形図をスキャナーを利用して，地形データと同じ範囲 を切り取った。このときスキャナーから読み込んだ画像デ ータの 2 值化を行い, モノクロの画像に変換した。次に, 地質体の分布等を画像処理ソフトウェアを利用して，それ ぞれのデー夕に対応した指定された色で着色を行った。本 テストデータでは，地形判読結果，ボーリングデータ，走 行傾斜デー夕を画像にそれぞれ色塗りを行いデータ分布フ アイルとした(第 12 図). 第 12 図では，ポイントデータ・走 向傾斜デー夕の分布をわかりやすくするために，ポイント データ点をのの記号で, 走向傾斜データ点は一般的に使用 される記号で表示している，今回作成したデータ分布ファ イルの画像サイズは $884 \times 532$ である.データ分布ファイ ルで使用した色数は，地質体に 3 色，ポイントデータに 12 色，走向傾斜データに 2 色の計 17 色とした.

\section{(3)地形データファイル}

地形データファイルのテストデータの作成は，STRIPE 法(Noumi;2003)を利用して行った。作成したテストデータ は $150 \times 101$ の格子数の DEM であり，格子間隔は $20 \mathrm{~m}$ ある(第 13 図).

\section{(4)ポイントデータファイルの作成}

ポイントデータファイルは，標高情報に対して作成を行 う。テストデータでは，12本のボーリングデータをポイン トデータとして使用した。ボーリングデータからポイント データファイルを作成する手順を以下に説明する。

第 14 図に示すボーリング柱状図がデータとして手元にあ るとし，標高 $105 \mathrm{~m}$ に段丘層と菖蒲谷層の境界が存在する とする。また，地質構造の論理モデルファイルの段丘層に 対応する色が黄色 (R:255,G:255,B:0), 菖蒲谷層に対応する 色が水色 (R:128,G:128,B:255)であるとし，デー夕分布ファ イル上のこの地点の RGB 值が (R:0,G:0,B:160)であるとす る。このとき, 境界面の上下に存在する 2 つの地層に対し て次の作業を行う。ポイントデータの左列(1から 3 列目ま で)から，デー夕分布図上の位置の RGB 值(R:0,G:0,B:160)を 入力， 4 列目に境界面の標高 $(105)$ を入力する. $5 \sim 7$ 行目に は，分布する段丘層と菖蒲谷層に対応する RGB 值をそれぞ れ 1 行目(段丘層の色值) と 2 行目 (菖蒲谷層の色值)に入力す る。この作業をすべてのデータに対して行う。テストデー
タとして作成したポイントデータファイルを第 15 図に示す.

\section{(5)走向傾斜データファイルの作成}

走向傾斜デー夕を使用する場合に作成する。テストデー 夕では，第 16 図に示すように 2 地点の走向傾斜データの入 力を行った。データの作成として, 左列からデータ分布図 に使用したRGB 值(256 階調)，走向(方位角)，傾斜の順に 入力したデータを使用する。

これらのデータを，プログラムに入力して，境界面 $S_{1}$ の等 式・不等式制約条件ファイルと走向傾斜ファイル，境界面 $S_{2}$ の等式・不等式制約条件ファイルを得た。 また，作成さ れたこれらのデータをHorizon2000(塩野ほか;2001)に入力 して境界面の推定を行った。推定結果をそれぞれ，第 17 図(a)に和泉層群と菖蒲谷層の境界面である $S_{1}$, 第 17 図(b) に和泉層群, 菖蒲谷層と段丘層の境界面である $S_{2}$ を示す。 また，Geomodel2003(米澤ほか;2004)を用いて，推定した境 界面と地質構造の論理モデルを用いて構築した三次元地質 モデルを第 18 図に示す。第 18 図(a)に三次元地質モデルの 鳥㒈図，第 18 図(b)に三次元地質モデルの平面図，第 18 図 (c)に三次元モデルの断面図をそれぞれ示す. 第 18 図(c)の 断面の位置は，第 18 図(b)の矢印で示した.

\section{5. おわりに}

本研究では, 地質構造の論理モデルを用いた, 露頭デー タやボーリングデータから三次元地質モデル構築に必要と なる境界面を推定するためのデータ作成プログラム Georiginerの開発を行った。また，テストデータを用いた データの作成，プログラムの使用方法，三次元地質モデル の一連の作業手順を示した。これにより，野外データから 境界面を推定するためのデータの作成が容易になると考え られる。今後，本研究で開発したプログラムを利用して， 実際のデータを使用した三次元地質モデルの構築を行い, さらに改良を進めていく予定である.

本誌で示したプログラム『Georiginer』は，日本情報地 質学会のホームページ(http://www.jsgi.org/)上でダウンロー ドできる。

\section{文 献}

Masumoto, S., Raghavan, V., Yonezawa, G., Nemoto, T. and Shiono, K. (2004) Construction and Visualization of a Three dimensional geologic model using GRASS GIS. Transactions in GIS, vol.8, no.2, pp.211-223.

Noumi, Y. (2003) Generation of DEM Using Inter-Contour Height Information on Topographic Map. Journal of Geosciences, Osaka City Univ., vol. 46, pp. 217-230.

坂本正徳 ·塩野清治 · 升本眞二 (2001) Terramod2001 - 地層 面推定.表示ソフトゥェア一。情報地質, vol. 12, no.2, pp. 112-113.

Shiono, K., Masumoto, S. and Sakamoto, M. (1994) On Formal 
Expression of Spatial Distribution of Strata Using Boundary Surfaces $-\mathrm{C}_{1}$ and $\mathrm{C}_{2}$ Type of Contact - Geoinformatics, vol.5, no.4, pp.223-232.

塩野清治 ·升本眞二 ・坂本正徳 (1998) 地層の 3 次元分布の 特性と地質図作成のアルゴリズム-地質構造の論理モデ ル-. 情報地質, vol.9, no.3, pp.121-134.

塩野清治 · 能美洋介 · 升本真二 ·坂本 · 正徳 (2001) Horizon 2000 ：等式・不等式制約条件や傾斜デー夕を活用した地
層面推定プログラムの改良．情報地質, vol.12, no.4, pp.229-249.

山根裕之・榊原辰雄 (1992) 3 次元地質解析システム「GEORAMA ver.3.0」. 日本情報地質学会講演貝講演予稿集, vol.3, pp. 57-58.

米澤 剛 · 升本眞二 ·根本達也 ·坂本正徳 ·塩野清治(2004) 拡張地質関数を用いた地質境界線の表示. 情報地質, vol.14, no.4, pp.193-206.

\section{要 旨}

\section{野外調査データから地質境界面推定データ作成プログラム『Georiginer』の開発}

: 梶山 敦司 ·居川 信之・塩野清治

地質構造の論理モデルは，境界面と地質体の論理的関係を表している。この論理的関係を用いることによって，地 質体の分布位置から地質境界面を推定するための制約条件を与えることが可能となる。本研究では, 地質構造の論理 モデルのこの特性を利用した境界面を推定するためのデータ作成プログラム Georiginerの開発を行った．本プログラ ムは, 露頭, ボーリングデータ, 走行傾斜データなどの位置情報をデータ分布図として与え, デー夕分布図と地質構 造の論理モデルを用いることによってそれぞれの野外データに対応した境界面の推定データの作成を行う。

キーワード：地質構造の論理モデル, 境界面, 画像デー夕, Georiginer 